\title{
Effect of Stocking Density on Survival, Growth and Production of Mud Crab Juvenile by Pen Culture System of Bangladesh
}

\section{Chakraborty BK* \\ Department of Fisheries, Matshya bhabon, Bangladesh}

*Corresponding author: Chakraborty BK, Department of Fisheries, Matshya bhabon, Ramna, Dhaka, Bangladesh, Email: bborty@gmail.com

\section{Research Article \\ Volume 2 Issue 4}

Received Date: April 23, 2018

Published Date: May 30, 2018

\section{Abstract}

Effect of stocking densities on the growth, survival and production of mud crab juvenile, genera Scylla was tested in a pen culture rearing system. Physico-chemical parameters were at the suitable level for culture period. The experiment was conducted for a rearing period of 135 days in nine pen culture earthen ponds having an area of 0.121 ha with an average depth of $0.90 \pm 0.13$ meter each. Juvenile of mud crabs stocked at $0.025,0.035$ and 0.45 million.ha-1 were designated as treatment $T_{1}, T_{2}$ and $T_{3}$. At stocking, all juveniles were with an initial mean carapace length, carapace width and weight of $2.80 \pm 0.02 \mathrm{~cm}, 4.10 \pm 0.04 \mathrm{~cm}$ and $45.80 \pm 0.80 \mathrm{~g}$ respectively. Highest mean carapace length, carapace width and weight gain was recorded in treatment $\mathrm{T}_{1}$ and lowest in treatment $\mathrm{T}_{3}$. Survival of juvenile followed the same trends as weight gain. Juvenile of mud crab in treatment $\mathrm{T}_{1}$ produced significantly higher specific growth rate than treatment $\mathrm{T}_{2}$ and $\mathrm{T}_{3}$. Feed conversion ratio was significantly lower in treatment $T_{1}$ followed by treatment $T_{2}$ and $T_{3}$ in that order. Significantly higher number of juveniles was produced in treatment $T_{3}$ than in treatment $T_{2}$ and $T_{1}$, respectively. In despite of this, consistently higher net benefits were found from treatment $T_{1}$ than from treatment $T_{3}$ and $T_{2}$, and also significant $(P<0.05)$. Overall, highest growth, survival and net benefits of mud crab juvenile was found at a density of 0.025 million juvenile.ha-1. Identification of mud crab species were Scylla serrata and Scylla olivacea and percentage of Scylla serrata was 44.82, 29.40 and $26.77 \%$ from treatment $\mathrm{T}_{1}, \mathrm{~T}_{2}$ and $\mathrm{T}_{3}$ and significantly lower than Scylla olivacea. Therefore, of the three stocking densities, 0.025 million juvenile.ha- ${ }^{-1}$ appears to be most suitable stocking density for rearing of mud crab juvenile pen culture system.

Keyword: Juvenile; Mud crab; Stocking density; Carapace width; Growth; Survival; Benefits

\section{Introduction}

The mud crab genera Scylla is widely distributed in the Pacific and Indian Oceans, where it inhabits brackish coastal waters and estuaries and has a great potential for aquaculture. The most commonly cultured crab species is Scylla serrata due to its preference to estuarine habitats, less aggressive behavior and higher value [1]. Scylla serrata is successfully cultivated in many Southeast Asian 


\section{International Journal of Oceanography \& Aquaculture}

countries and fetches high prices in the international market.

In Taiwan, Scylla serrata has been reared in both polyculture (together with shrimps, milkfish and rice) and monoculture ponds [2,1]. In Philippines, the species has been cultured in ponds [3-5] as well as in pens [6]. In East Malaysia, pen culture has been practiced where the mud crabs are allowed to grow in their natural habitat in enclosures in mangroves [7].

Pen culture is to be originated in the inland sea area of Japan in the early 1920's [8] and adopted by the People's Republic of China in the 1950's for rearing of carps in freshwater lakes [9], and introduced to culture milkfish in the Philippines in the 1970's [10]. From there, it has been successfully extended for the culture of tilapia and carp [11]. At present, it is commercially practiced only in the Bangladesh, Philippines, Indonesia and China [9].

Rearing of mud crab juveniles practice is first introduced in Bangladesh under the project "Culture of. Cuchia and Crab in the Selected Area of Bangladesh and Research Project". No crab hatchery is not established in the country. So, mud crab culture practice is totally dependent on wild stock. Once the coastal area of Bangladesh had abundance of mud crab and wild fish species. Due to over exploitation and various ecological changes in the mangrove area, the population of mud crab is going to decrease. The mangrove area is under great stress and its existence is under danger because of changing aquatic ecosystems and habitat degradation. Indiscriminate destructive harvesting crab practices, soil erosion and lower salinity have caused havoc to the aquatic biodiversity of coastal area [12]. Mud crabs genera Scylla are importance as a source of delicious food and income throughout much of the tropical Indo-Pacific and as a consequence have been reduced, in both abundance and size, throughout much of their range [1315]. The mud crabs of the coastal area were subjected to over capturing resulting in gradual decline in crab population [12]. Mud crab was facing as higher risk of extinction day-by-day. To overcome the basic requirement of mud crab juvenile in the aquaculture mud crab field, hatchery should be established in the coastal region of Bangladesh. But until to establish crab hatchery in Bangladesh, eco-friendly catch system of mud crab and sustainable juvenile mud crab culture should be popularized in the coastal area to continue gonad development of crab in pen and case culture [12].
The rearing of mud crab juveniles, genera Scylla was undertaken in net pen in the coastal region of Bagherhat, Khulna and Satkhira districts and wild crab juveniles collected from the Sundarbon mangrove area. The present experiment has been undertaken to develop a practical and economically viable methodology rearing of mud crab juveniles and economic viability of mud crab production under controlled pen culture management system.

\section{Materials and Methods}

\section{Study Area, Culture Period and Experimental Design}

Experimental juvenile mud crab culture was conducted in net pens at the private pond of Shamnagar, Satkhira; Rampal, Bhagherhat and Dumuria, Khulna; Bangladesh (Figure. 1a, 1b and 1c). The experiment was conducted for a period of 135 days from $1^{\text {st }}$ September to 13 January 2016 in nine pens of earthen pond. The area of pen was 0.121 ha with an average depth of $0.95 \pm 0.13$ meter with a low turbidity, absence of pollutants, firm bottom condition and protection from high winds. The pen of ponds was having similar rectangular size and depth. The pen was fenced with monofilament nets of mesh size 5 $\mathrm{mm}$. The net was fixed to the bottom and supported with wooden pole. The height of the enclosures was maintained at $1.2 \mathrm{~m}$ during unfavorable climatic conditions. Saline water exchange in these enclosed water bodies was connected by tidal fluctuation. Three treatments with three replicates each were designed and differing in stocking densities of crab's juveniles was stocked.

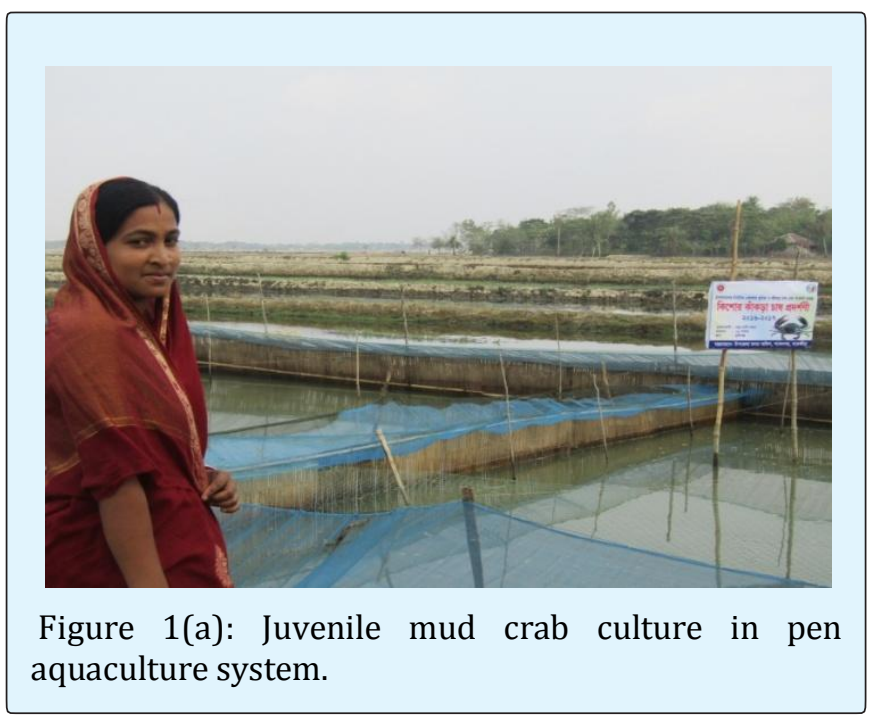




\section{International Journal of Oceanography \& Aquaculture}
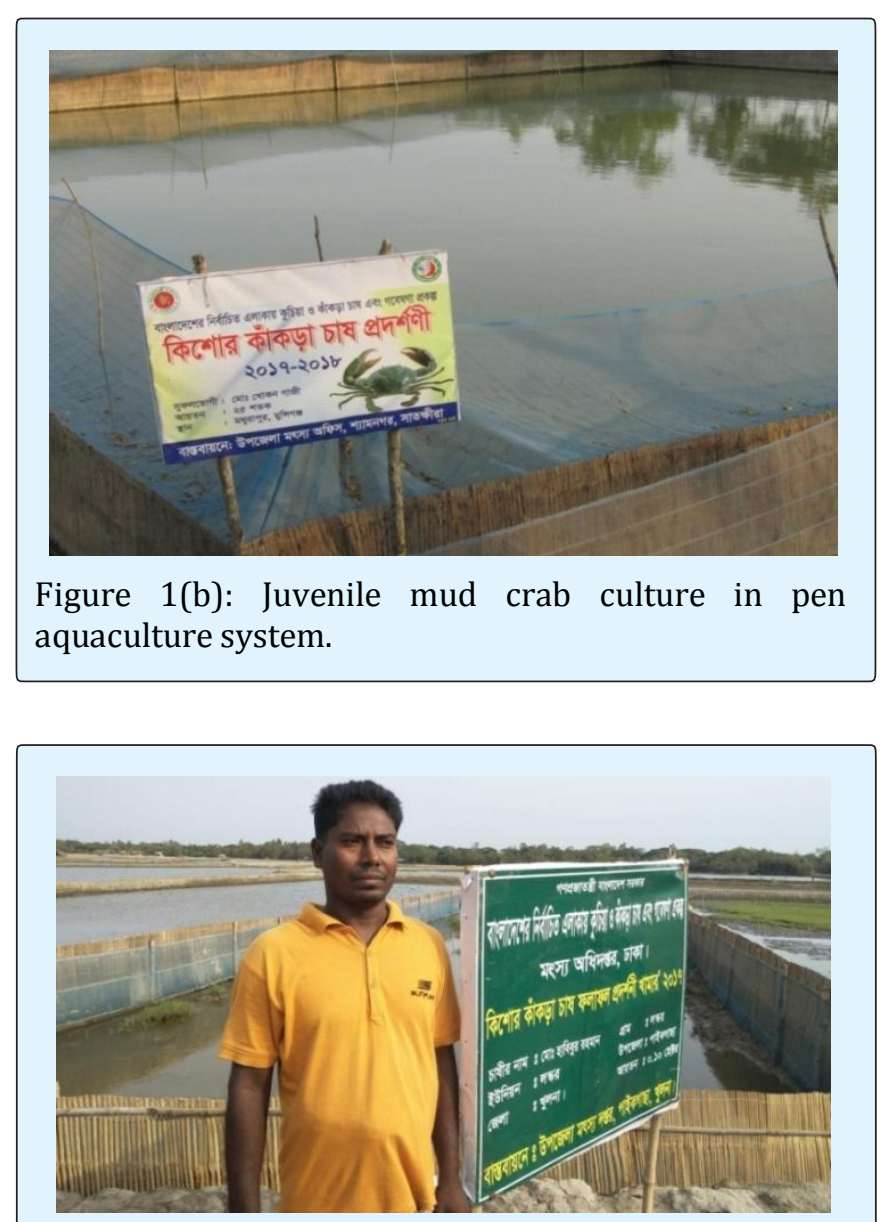

Figure 1(c): Juvenile mud crab culture in pen aquaculture system.

\section{Pond Preparation and Fertilization}

The ponds were dewatered, freed from aquatic vegetation, exposed to full sunlight and had a well designed system of inlet and outlet. After drying, quicklime $\left(\mathrm{CaCO}_{3}, 250 \mathrm{~kg}^{2} \mathrm{ha}^{-1}\right)$ was spread over the pond bottom. All the ponds were filled with saline water. Five days subsequent to liming, the ponds were fertilized with muster oilcake at the rate of $123.5 \mathrm{~kg} \cdot \mathrm{ha}^{-1}$.

\section{Stocking}

The experimental ponds were stocked with an initial weight of $45.80 \pm 0.80 \mathrm{gm}$ old mud crab juvenile. Stocking densities were 0.025 million.ha ${ }^{-1}$ (treatment $\mathrm{T}_{1}$ ), 0.035 million.ha ${ }^{-1}$ (treatment $\mathrm{T}_{2}$ ) and 0.045 million.ha $^{-1}$ (treatment $\mathrm{T}_{3}$ ).

\section{Supplementary Feeding}

In order to meet the increasing dietary demand, trash fish including tilapia as feed was supplied at the rate of $03-6 \%$ of their total biomass twice daily commencing from the first day of stocking. The rate of feeding was maintained $6 \%$ depending on carapace length $<4-6 \mathrm{~cm}$, $5 \%$ depending on carapace width $<6-7 \mathrm{~cm}, 4 \%$ depending on carapace width $<7-8 \mathrm{~cm}$ and $3 \%$ depending on carapace width $<8-9 \mathrm{~cm}$ and $2 \%$ depending on carapace width $<9-11 \mathrm{~cm}$. Trash fish was provided twice daily, $40 \%$ of the ration in the morning and $60 \%$ in the evening commencing from the first day of stocking. Daily ration was adjusted by estimating the standing crop once in each fortnightly by random sampling of the stock.

\section{Water Quality Parameters}

Physico-chemical parameters of pond water were monitored fortnightly between 9.00 and $10.00 \mathrm{~h}$. Water temperature was recorded using a Celsius thermometer and salinity of water was measured by Refactometer. Dissolved oxygen and $\mathrm{pH}$ were measured directly using a digital electronic oxygen meter (YSI, Model 58, USA) and an electronic pH meter (Jenway, Model 3020, UK).

\section{Estimation of Growth, Survival, Production and Feed Utilization}

Total yield $(\mathrm{kg})$ and number of S. serrata harvested from each pen of the pond were recorded. Twenty percent of the population from each pond was randomly sampled and individually weighed with the help of a portable sensitive balance (Model HL $400 \mathrm{EX}$ ) and measured for carapace length (CL) and carapace width (CW) with measuring venire calipers until they attained marketing size. Growth in terms of weight, Average daily gain (ADG), Specific Growth Rate (SGR) and Food conversion ratio (FCR) was estimated. SGR and FCR were calculated according to Brown [16]; Castell and Tiews [17] and Gangadhara, et al., [18], respectively. After 135 days, the crabs were harvested by trap and draining or drying the ponds. The number of species were counted and weighed. Survival (\%) and production (wt.ha ${ }^{-1}$ ) of crabs were then calculated and compared among the treatments.

\section{Identification of Mud Crab Species and Percentage}

Mud crabs genera Scylla was identified depending on colour, size, spintion and habitat according to Keenan, et al. [19]. 


\section{International Journal of Oceanography \& Aquaculture}

\section{Economic Analysis}

The cost analysis was in terms of hectare to maintain a standard unit. Cost-return and partial budgeting analyses were done to compare the viability and profitability of the various treatments used [20].

\section{Analysis of Experimental Data}

The data were analyzed through one way analysis of variance (ANOVA) using MSTAT followed by Duncan's New Multiple Range test to find out whether any significant difference existed among treatment means [21-23]. Standard deviation in each parameter and treatment was calculated and expressed as mean \pm S.D. In all statistical analysis, the difference was considered to be significant when $\mathrm{P}<0.05$.

\section{Results}

\section{Water Quality Parameters}

Mean levels of physico-chemical parameters over the 135 days culturing mud crab juveniles are presented in
Table 1. The temperature recorded in treatment $T_{1}, T_{2}$ and $\mathrm{T}_{3}$ was from September to January varied between $19.80^{\circ} \mathrm{C}$ and $30.78^{\circ} \mathrm{C}$. The mean water temperatures in treatment $T_{1}, T_{2}$ and $T_{3}$ were not statistically significant $(P>0.05)$. The salinity in treatment $\mathrm{T}_{1}, \mathrm{~T}_{2}$ and $\mathrm{T}_{3}$ were fluctuated between 7.35 and 18.22 ppt due to mixing estuarine saline water. Salinity was recorded suitable range in the treatment $\mathrm{T}_{1}(14.18 \pm 2.97 \mathrm{ppt})$ and differed significantly $(P<0.05)$ among treatment $\mathrm{T}_{2}$ and $\mathrm{T}_{3}$. The highest $\mathrm{pH}$ was recorded in treatment $\mathrm{T}_{1}(7.77 \pm 0.15)$ and $\mathrm{pH}$ decreased from $\mathrm{T}_{1}$ to $\mathrm{T}_{3}$ but did not differ significantly $(P>0.05)$. The $\mathrm{pH}$ recorded in treatment $\mathrm{T}_{1}, \mathrm{~T}_{2}$ and $\mathrm{T}_{3}$ was from September to January varied between 7.50 and 8.12 . Highest range of dissolved oxygen was recorded in treatment $\mathrm{T}_{1}\left(5.62 \pm 0.85 \mathrm{mg.l}^{-1}\right)$ and lowest range of dissolved oxygen was recorded in treatment T3. However, there were no significant variations $(P>0.05)$ in the value of dissolved oxygen among the different treatments. Despite these variations, water quality parameters in all the experimental treatments were within the normal range for juvenile mud crab culture (Table 1).

\begin{tabular}{|c|c|c|c|}
\hline \multirow{2}{*}{ Parameter } & \multicolumn{3}{|c|}{ Treatment } \\
\cline { 2 - 4 } & $\mathbf{T}_{\mathbf{1}}$ & $\mathbf{T}_{\mathbf{2}}$ & $\mathbf{T}_{\mathbf{3}}$ \\
\hline \multirow{2}{*}{ Temperature (0c) } & $25.45 \pm 6.99$ & $25.25 \pm 6.08$ & $25.38 \pm 6.22$ \\
\cline { 2 - 4 } & $(20.8030 .70)$ & $(20.11-30.78)$ & $(19.80-29.95)$ \\
\hline \multirow{2}{*}{ Salinity (ppt or 0/00) } & $14.18 \pm 2.97^{\mathrm{a}}$ & $12.35 \pm 3.01^{\mathrm{b}}$ & $10.01 \pm 4.10^{\mathrm{c}}$ \\
\cline { 2 - 4 } & $(9.10-18.22)$ & $(8.22-17.88)$ & $(7.35-16.68)$ \\
\hline \multirow{2}{*}{$\mathrm{pH}$} & $7.80 \pm 0.15$ & $7.71 \pm 0.19$ & $7.70 \pm 0.16$ \\
\cline { 2 - 4 } & $(7.60-8.12)$ & $(7.62-8.05)$ & $(7.50-8.00)$ \\
\hline \multirow{2}{*}{ Dissolved oxygen (mg/L) } & $5.62 \pm 0.85$ & $5.41 \pm 0.56$ & $5.55 \pm 0.88$ \\
\cline { 2 - 4 } & $(5.10-6.15)$ & $(4.90-6.00)$ & $(5.01-6.18)$ \\
\hline
\end{tabular}

Table 1: Physico-chemical characters of water in the pen of juvenile ponds during the experimental period. Figure in the same row having the same superscript is significantly different $(\mathrm{P}>0.05)$.

Figure in the parenthesis indicates the range.

\section{Growth, Feed Utilization and Production of Fish}

The growth and production of young crabs in term of gain in number and weight under three treatments were investigated and monitored fortnightly. The results obtained are presented in Table 2, and Figure $2(a \& b)$ and 3 ; which indicated that the growth in terms of number and weight showed much variation in different treatment and continued till final harvesting. During the investigation, final weight of crab was recorded to be $298.50 \pm 4.05, \quad 240.22 \pm 3.34$ and $192.32 \pm 3.01 \mathrm{~g}$ in treatment $T_{1}, T_{2}$ and $T_{3}$, respectively. The increase in weight mud crab was the highest in $\mathrm{T}_{1}$ followed by $\mathrm{T}_{2}$ and
$\mathrm{T}_{3}$, respectively. The initial carapace length, carapace width and weight $(2.60 \pm 0.02 \mathrm{~cm}, 4.10 \pm 0.04 \mathrm{~cm}$ and $45.80 \pm 0.80 \mathrm{~g}$ ) of juvenile stocked in all the ponds were the same. The juvenile in treatment $\mathrm{T}_{1}$ showed the highest gain in carapace length, carapace width and weight $(6.10 \pm 1.01 \mathrm{~cm}, \quad 10.60 \pm 1.88 \mathrm{~cm}$ and $298.50 \pm 4.05 \mathrm{~g})$ compared to the treatments $\mathrm{T}_{2}$ and $\mathrm{T}_{3}$, where stocking density of fingerlings was 0.030 million. ha $^{-1}$. However, the mean final weight of mud crab juveniles in different treatments were significantly different $(P<0.05)$. SGR in treatment $\mathrm{T}_{1}$ was significantly higher than in $\mathrm{T}_{2}$ and $\mathrm{T}_{3}$ $(P<0.05)$. Food conversion ratio was significantly lower in $\mathrm{T}_{1}$ than $\mathrm{T}_{2}$ and $\mathrm{T}_{3}$. Therefore, best SGR $(1.39 \pm 0.04)$ and 


\section{International Journal of Oceanography \& Aquaculture}

FCR $(1.91 \pm 0.02)$ were recorded in treatment $\mathrm{T}_{1}$ where lowest number of juvenile of crab was reared. The highest survival rate $(64.10 \pm 2.14)$ was also observed in $\mathrm{T}_{1}$ and the lowest $(40.52 \pm 3.30)$ in $\mathrm{T}_{3}$. There was a significant variation $(P<0.05)$ in the survival rate in juvenile of crabs among different treatments. The net production of crab was $\quad(4783.44 \pm 6.94 \mathrm{~kg}), \quad(4324.72 \pm 9.13 \mathrm{~kg}) \quad$ and
$(3506.76 \pm 10.03 \mathrm{~kg})$ ha $^{-1}$.days ${ }^{-135}$ in treatment $\mathrm{T}_{1}, \mathrm{~T}_{2}$ and $\mathrm{T}_{3}$, respectively. Total production of mud crab was recorded to be higher in treatment $\mathrm{T}_{1}$ and lowest in treatment $\mathrm{T}_{3}$. On the other hand, highest number of juveniles was stocked in treatments $\mathrm{T}_{3}$, where lowest production was recorded and differed significantly $(P<0.05)$ from $\mathrm{T}_{1}$ and $\mathrm{T}_{2}$ (Table 2$)$.

\begin{tabular}{|c|c|c|c|}
\hline \multirow{2}{*}{ Parameters } & \multicolumn{3}{|c|}{ Treatments } \\
\hline & $T_{1}$ & $\mathbf{T}_{2}$ & $\mathbf{T}_{3}$ \\
\hline Initial carapace length $(\mathrm{cm})$ & $\begin{array}{c}2.60 \pm 0.02 \\
(2.10-2.98)\end{array}$ & $\begin{array}{c}2.60 \pm 0.02 \\
(2.10-2.98)\end{array}$ & $\begin{array}{c}2.60 \pm 0.02 \\
(2.10-2.98)\end{array}$ \\
\hline Final carapace length $(\mathrm{cm})$ & $\begin{array}{l}6.10 \pm 0.47 \\
(5.60-6.50)\end{array}$ & $\begin{array}{c}5.44 \pm 0.44 \\
(4.95-5.80) \\
\end{array}$ & $\begin{array}{l}4.95 \pm 0.56 \\
(4.3-5.31) \\
\end{array}$ \\
\hline Initial carapace width $(\mathrm{cm})$ & $\begin{array}{l}4.10 \pm 0.04 \\
(3.00-4.50)\end{array}$ & $\begin{array}{l}4.10 \pm 0.04 \\
(3.00-4.50)\end{array}$ & $\begin{array}{c}4.10 \pm 0.04 \\
(3.00-4.50)\end{array}$ \\
\hline Final carapace width $(\mathrm{cm})$ & $10.60 \pm 1.88(6.20-11.30)$ & $10.00 \pm 2.00(6.00-11.10)$ & $\begin{array}{c}9.50 \pm 2.20 \\
(5.90-11.00) \\
\end{array}$ \\
\hline Initial body weight (g) & $45.80 \pm 0.80(40.40-50.66)$ & $45.80 \pm 0.80(40.40-50.66))$ & $\begin{array}{c}45.80 \pm 0.80 \\
(40.40-50.66)\end{array}$ \\
\hline Final body weight (g) & $\begin{array}{c}298.50 \pm 4.05^{\mathrm{a}}(260.08- \\
311.64)\end{array}$ & $240.22 \pm 3.34^{a}(211.14-260.24)$ & $192.32 \pm 3.01^{\mathrm{a}}(167.22-215.22)$ \\
\hline Net weight gain (g) & $\begin{array}{c}252.70 \pm 3.01^{\mathrm{a}}(233.12- \\
277.66)\end{array}$ & $194.42 \pm 3.228^{b}(166.10-209.32)$ & $146.52 \pm 3.34^{b}(122.01-176.82)$ \\
\hline Average daily gain(g) & $\begin{array}{l}1.87 \pm 0.03^{\mathrm{a}} \\
(1.64-1.98)\end{array}$ & $\begin{array}{l}1.44 \pm 0.04^{\mathrm{b}} \\
(1.31-1.68)\end{array}$ & $\begin{array}{l}1.09 \pm 0.05^{c} \\
(0.95-1.35)\end{array}$ \\
\hline Specific growth rate & $\begin{array}{l}1.39 \pm 0.04^{\mathrm{a}} \\
(1.31-1.46)\end{array}$ & $\begin{array}{l}1.23 \pm 0.04^{\mathrm{b}} \\
(1.15-1.28)\end{array}$ & $\begin{array}{l}1.06 \pm 0.05^{c} \\
(1.01-1.12)\end{array}$ \\
\hline Survival rate (\%) & $64.10 \pm 2.14^{\mathrm{a}}(62.80-66.20)$ & $\begin{array}{c}51.44 \pm 3.08^{\mathrm{b}} \\
(50.02-54.30)\end{array}$ & $\begin{array}{c}40.52 \pm 3.30^{c} \\
(44.80-49.80)\end{array}$ \\
\hline FCR & $\begin{array}{l}1.91 \pm 0.02^{\mathrm{a}} \\
(1.70-1.96)\end{array}$ & $\begin{array}{l}2.04 \pm 0.04^{b} \\
(1.95-2.10)\end{array}$ & $\begin{array}{l}2.10 \pm 0.05^{c} \\
(1.98-2.18)\end{array}$ \\
\hline Production\#/ha & $\begin{array}{c}16025 \pm 17.58^{\mathrm{a}}(14910- \\
16843)\end{array}$ & $18004 \pm 20.07^{b}(17881-18661)$ & $18234 \pm 30.05^{c}(18142-18492)$ \\
\hline Production (kg.ha-1) & $\begin{array}{c}4783.44 \pm 6.94 \mathrm{a}(4705.42- \\
4891.35)\end{array}$ & $\begin{array}{c}4324.72 \pm 9.13^{\mathrm{b}}(4302.38- \\
4409.10)\end{array}$ & $\begin{array}{c}3506.76 \pm 10.03^{c}(3480.42- \\
3591.35)\end{array}$ \\
\hline
\end{tabular}

Table 2: Survival, feed conversion ratio (FCR), Growth performance and production of Scylla serrata juveniles after 135 days of rearing; mean \pm S.D. with ranges in parentheses.

Figure in the same row having the same superscript are not significantly different $(\mathrm{P}>0.05)$. Values in the parenthesis indicate the range.

\# Total crop of crabs harvested after 135 days.

Average daily gain $(\mathrm{g})=($ mean final weight - mean initial weight) / time interval (days).
Specific growth rate $(\mathrm{SGR})=\mathrm{Ln}$ mean final weight $-\mathrm{Ln}$ mean initial weight)/time interval (days) $\times 100$.

FCR $($ Food conversion ratio $)=$ Total diet fed $(\mathrm{kg}) /$ total wet weight gain $(\mathrm{kg})$. 


\section{International Journal of Oceanography \& Aquaculture}

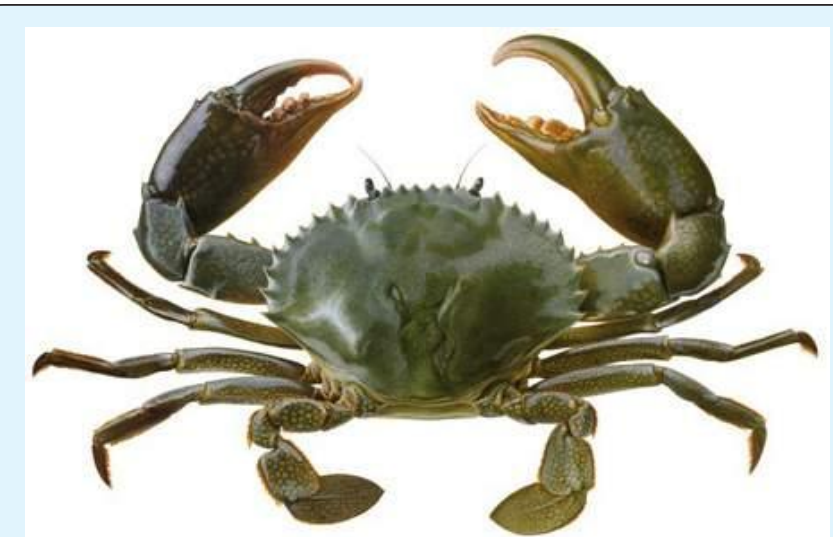

Figure 2(a): Scylla serrata identified in the three treatments.

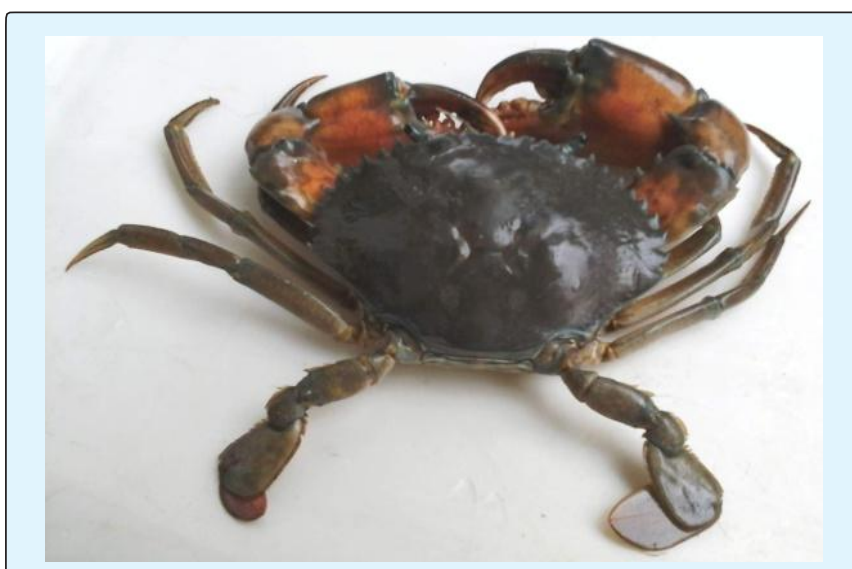

Figure 2(b): Scylla olivacea identified in the three treatments.

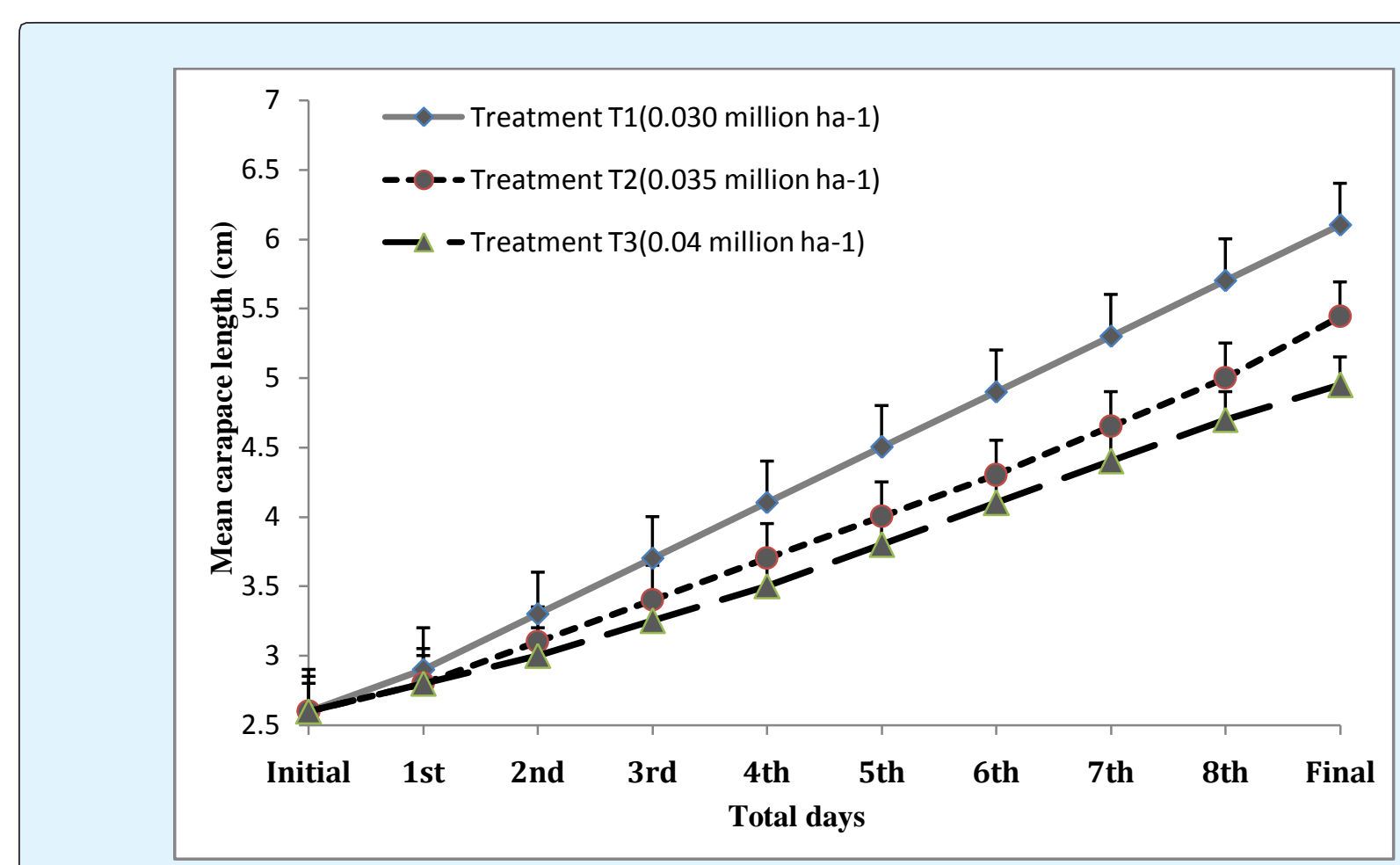

Figure 3: 15 day's interval means Carapace length $(\mathrm{cm})$ of mud crab juvenile genera Scylla under different density.

\section{Identification of Mud Crab Species and Percentage}

About two species of mud crab Scylla serrata and Scylla olivacea were identified (Figure 4). The percentage of S. serrata was $44.82,29.40$ and $26.77 \%$ and S. olivacea was $55.18,70.76$ and $73.23 \%$ from treatment $\mathrm{T}_{1}, \mathrm{~T}_{2}$ and $\mathrm{T}_{3}$.
There was a significant variation $(\mathrm{P}<0.05)$ in the percentage between $\mathrm{S}$. serrata and $\mathrm{S}$. olivacea among different treatments. Total production of S. serrata was found $2343.74 \pm 4.08,1391.47 \pm 3.88$ and $1038.46 \pm 3.99 \mathrm{~kg}$ in treatment $\mathrm{T}_{1}, \mathrm{~T}_{2}$ and $\mathrm{T}_{3}$ (Figure 5) which was significantly $(\mathrm{P}<0.05)$ different in different treatments. 


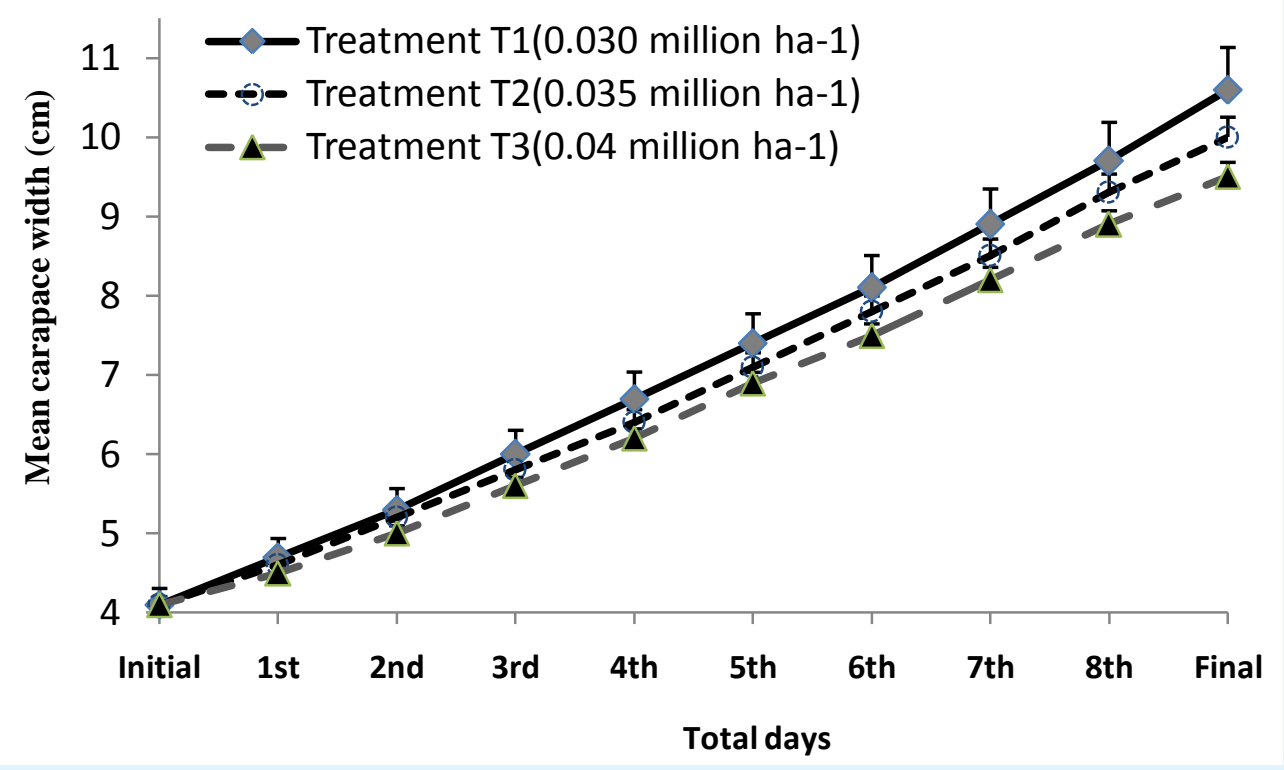

Figure 4: 15 day's interval means Carapace width (cm) of mud crab juvenile genera Scylla under different density.

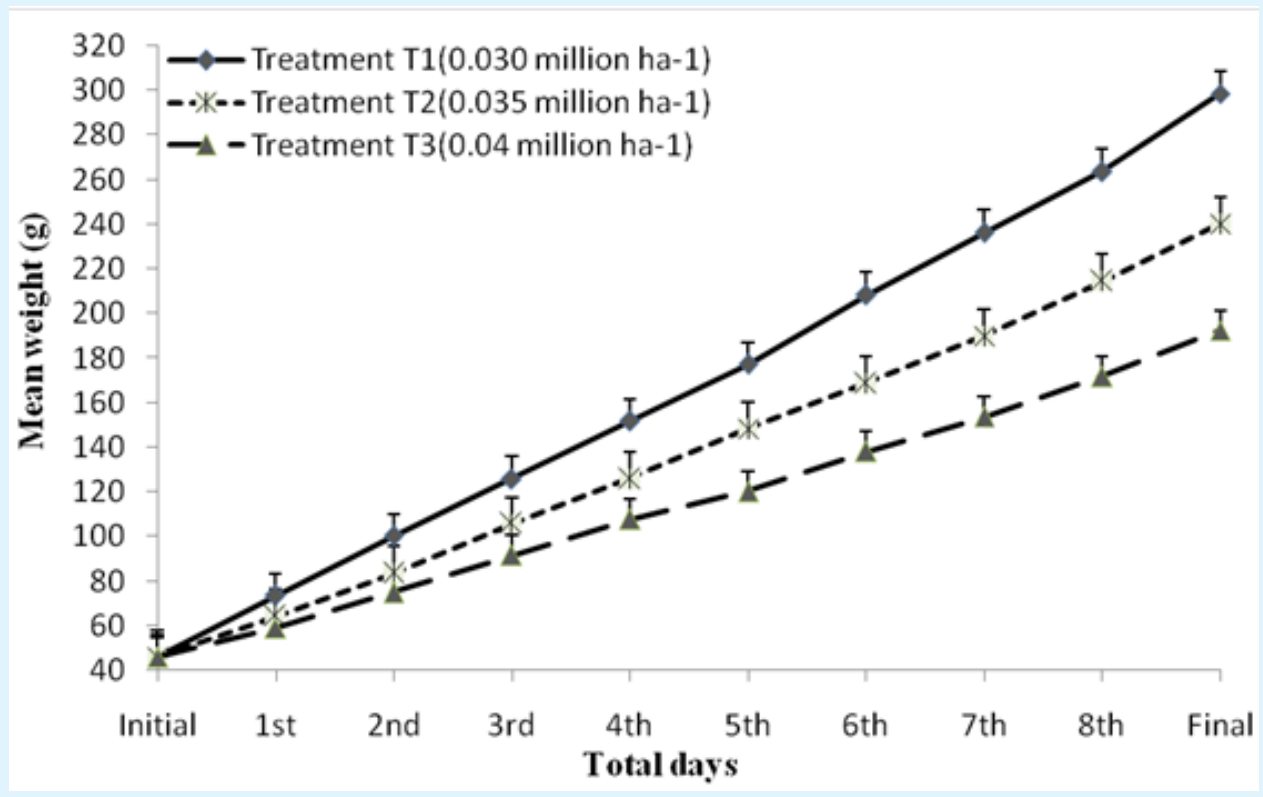

Figure 5: About 15 day's interval means weight gain (g) of mud crab juvenile genera Scylla under different density.

\section{Net Benefit}

Total cost production in treatment $\mathrm{T}_{1}, \mathrm{~T}_{2}$ and $\mathrm{T}_{3}$ was recorded BDTk. 1084810, 1123039 and 1122663 respectively. On the other hand, cost of production in treatment $\mathrm{T}_{1}$ was consistently higher than those treatments $\mathrm{T}_{2}$ and $\mathrm{T}_{3}$ (Table $3 \& 4$ ). Highest net return (in term of Bangladeshi Tk.ha ${ }^{-1}$ and one US\$ = Bangladeshi TK. 83) was obtained in treatment $\mathrm{T}_{1}$ (BdTk. 1545840) followed by $\mathrm{T}_{2}$ (BdTk. 822761) and $\mathrm{T}_{3}$ (BdTk. 280041) in that order. 


\section{International Journal of Oceanography \& Aquaculture}

\begin{tabular}{|c|c|c|c|c|c|c|c|c|c|}
\hline \multirow[b]{2}{*}{$\begin{array}{c}\text { Species } \\
\text { Name }\end{array}$} & \multicolumn{3}{|c|}{ Treatment $\mathbf{T}_{1}$} & \multicolumn{3}{|c|}{ Treatment $\mathbf{T}_{2}$} & \multicolumn{3}{|c|}{ Treatment $\mathrm{T}_{3}$} \\
\hline & $\begin{array}{c}\text { Number } \\
\text { (\#) }\end{array}$ & $\begin{array}{c}\text { Percentage } \\
(\%)\end{array}$ & $\begin{array}{c}\text { Production } \\
\text { (kg) }\end{array}$ & $\begin{array}{c}\text { Number } \\
\text { (\#) }\end{array}$ & $\begin{array}{c}\text { Percentage } \\
(\%)\end{array}$ & $\begin{array}{c}\text { Production } \\
\text { (kg) }\end{array}$ & $\begin{array}{c}\text { Number } \\
\text { (\#) }\end{array}$ & $\begin{array}{c}\text { Percentage } \\
(\%)\end{array}$ & $\begin{array}{c}\text { Production } \\
\text { (kg) }\end{array}$ \\
\hline $\begin{array}{c}\text { Scylla } \\
\text { serrata }\end{array}$ & 7182 & 44.82 & $2343.74 \pm 4.08$ & 5294 & 29.4 & $1391.47 \pm 3.88$ & 48.81 & 27 & $1038.46 \pm 3.99$ \\
\hline $\begin{array}{c}\text { Scylla } \\
\text { olivacea }\end{array}$ & 843 & 55.18 & $2439.7 \pm 8.22$ & 12710 & 70.8 & $2933.25 \pm 8.63$ & 13353 & 73 & $2468.3 \pm 9.58$ \\
\hline Total & 16025 & 100 & $\begin{array}{c}4783.44 \\
\pm 6.94^{\mathrm{a}}\end{array}$ & 18004 & 100 & $4324.72 \pm 9.13$ & 18234 & 100 & $\begin{array}{c}3506.76 \\
\pm 10.03\end{array}$ \\
\hline
\end{tabular}

Table 3: Identification of mud crab species, number, percentage and production of genera Scylla in three treatments.

\begin{tabular}{|c|c|c|c|c|}
\hline \multirow{3}{*}{ Item } & \multicolumn{3}{|c|}{ Amount TK•ha-1 $\bullet$ month $^{-2}$} & \multirow{3}{*}{ Remarks } \\
\hline & \multirow{2}{*}{ Treatment $\mathrm{T}_{\mathbf{1}}(\mathrm{Tk})^{\mathrm{a}}$} & \multirow{2}{*}{$\begin{array}{c}\text { Treatment } \\
T_{2}(\mathrm{Tk}) \\
\end{array}$} & \multirow{2}{*}{$\begin{array}{c}\text { Treatment } \\
T_{3}(\mathrm{Tk}) \\
\end{array}$} & \\
\hline & & & & \\
\hline Total return (TR) ${ }^{\mathrm{b}}$ & 2630650 & 1945800 & 1402704 & $\begin{array}{l}\text { Price is related with } \\
\text { size and weight }\end{array}$ \\
\hline \multicolumn{5}{|l|}{ a. Variable cost: } \\
\hline 1. Price of juvenile & 250000 & 350000 & 450000 & Tk. $10.00 \#^{-1}$ \\
\hline 2. Feed (Tk. 60.00/kg) & 616662 & 551044 & 450072 & \\
\hline 3. Fertilizer, lime etc. & 10112 & 10112 & 10112 & \\
\hline $\begin{array}{l}\text { 4. Human labour cost } \\
\text { (Tk.300.00/day) }\end{array}$ & 40500 & 40500 & 40500 & 01 labour day $^{-1}$ \\
\hline 5. Chemicals & 4008 & 4380 & 5010 & \\
\hline 6. Miscellaneous & 20000 & 20000 & 20000 & With netting \\
\hline Total Variable cost (TVC) & 991282 & 976036 & 975694 & \\
\hline \multicolumn{4}{|l|}{ b. Fixed cost : } & \multirow{4}{*}{\begin{tabular}{|c|} 
Tk. 200.00 dec $^{-1}$ \\
according to local rate. \\
$10 \%$ interest according \\
to BKB, Bangladesh
\end{tabular}} \\
\hline 1.Pond rental value & 49400 & 49400 & 49400 & \\
\hline 2.Interest of operating capital & 94128 & 97603 & 97569 & \\
\hline Total fixed cost (TFC) & 143528 & 147003 & 146969 & \\
\hline Total cost $(\mathrm{TC}=\mathrm{TVC}+\mathrm{TFC})$ & 1084810 & 1123039 & 1122663 & \\
\hline Gross margin (GM= TR-TVC) & 1689368 & 943764 & 427010 & \\
\hline Net return (TR-TC) & 1545840 & 822761 & 280041 & \\
\hline
\end{tabular}

Table 4: Cost and benefits from the juvenile of genera Scylla in 1-ha earthen ponds for a period of 135 days.

a1 US\$ = BDTk. 83.00

$\#=$ Number

$\mathrm{BKB}=$ Bangladesh Krishi Bank

Figures with different superscripts in the same row varied significantly $(P<0.05)$. Figures in the parenthesis indicate range.

bale price Tk.550.00 kg-1 $\left(\mathrm{T}_{1}\right)$, Tk.450.00 $\mathrm{kg}^{-1}\left(\mathrm{~T}_{2}\right)$ and Tk.400.00 $\mathrm{kg}^{-1}\left(\mathrm{~T}_{3}\right)$.

\section{Discussion}

The environmental parameters exert an immense influence on the maintenance of a well aquatic environment and production of food organisms. Growth, feed efficacy and feed consumption of fish are normally governed by a few environmental factors [24]. The physico-chemical parameters recorded in the nine ponds 


\section{International Journal of Oceanography \& Aquaculture}

were favorable for the growth and survival of the crabs. For experimental period, the water temperature in three treatments $T_{1}, T_{2}$ and $T_{3}$ was conducive to the growth of the crab juvenile. The salinity in three treatments $T_{1}, T_{2}$ and $\mathrm{T}_{3}$ was relatively more stable; due to a good water exchange in the pen during the culture period as the enclosure was located close to the seawater inlet. The favorable salinity range for mud crab culture was suitable which is agreed by Bhuiyan and Islam [25]. The $\mathrm{pH}$ values agreed well with the findings of APHA [26], Clesceri, et al. [27] and Chakraborty, et al. [12]. The dissolved oxygen in the morning was low in ponds stocked with a high density of fish compared to ponds stocked with a low density. Similar results were observed by Boyd [28] and APHA [26].

The stocking densities of the juvenile were 0.025 million ha-1 (treatment $\mathrm{T}_{1}$ ), 0.035 million ha-1 $^{-1}$ (treatment $\mathrm{T}_{2}$ ) and 0.045 million ha ${ }^{-1}$ (treatment $\mathrm{T}_{3}$ ), respectively; which were substantially higher compared to other trial cultures conducted in Taiwan by Chen, 1990 [29]. Cannibalism was found in different treatments which are agreed by Baliao DD, et al. [30-32]. They found common in mud crab culture when high stocking densities and mixed sex culture are practiced.

Survival of mud crab for the present study was recorded at the range from 46.44 to $60.10 \%$ which is agreed by Trino, et al. [33,5]. He reported that the loss of young crabs grown in ponds for a period of 3 to 8 months can be relatively high, from $40 \%$ to $60 \%$, if the stocking rates are high. The three stocking densities $(0.025,0.035$ and 0.045 million ha-1) for mud crab used in the study were within the range recommended by Trino, et al. [33]. In this study, the survival was lower due to highly cannibalistic character of mud crab and long culture period, which agreed by Trino, et al. [33]. The pen in three treatments had a firm and muddy bottom with pieces of plastic pipe and grass. In this study, plastic pipe and grass of juvenile culture acted as crab shelter, minimizing mortality and loss of stock due to cannibalism [29]. Fielder, et al, [34] indicated that the application of crab shelter increased survival by minimizing antagonistic encounters.

Growth in terms of length, weight, weight gain and SGR of juvenile of genera Scylla was significantly higher in T1 where the stocking density was low compared to those of $\mathrm{T}_{2}$ and $\mathrm{T}_{3}$ although same food was supplied in all the treatments at an equal ratio. The low growth rate genera Scylla in treatment $T_{2}$ and $T_{3}$ appeared to be related with higher densities and increased competition for food and space and an inverse relationship with in the stocking density provided that space-limiting effects operate on the population $[7,2,35]$. In this experiment, at higher stocking densities, presence of abundant food substances could produce a comparative interaction among the population causing a stressful situation [36].

This experiment has shown that the crabs were able to grow in the pen, as indicated by the increase in SGR values in three treatments. Similar growth rates is recorded by Bensam [37] who found increase in weight ranging from 2.3 times to 3.5 times in a period of 3 months of culture. The lower FCR value in the present study indicates better food utilization efficiency, despite the values increased with increasing stocking densities. Significantly higher survival was noted in treatment $\mathrm{T}_{1}$, where, the stocking density was lower than $\mathrm{T}_{2}$ and $\mathrm{T}_{3}$. The reason for reduced survival rate in these treatments was due to higher stocking density of juvenile as well as competition for food and space in the experimental ponds [37].

In the present study, a significant lower number of juvenile was stocked in treatment $\mathrm{T}_{1}$ with 0.025 million juveniles.ha-1 than those of from the treatment $\mathrm{T}_{2}$ and $\mathrm{T}_{3}$ stocked with 0.035 and 0.045 million juveniles.ha-1, respectively. Despite this, consistently higher net benefits were obtained from ponds stocked with 0.025 million juveniles.ha-1 than those from the treatment $\mathrm{T}_{2}$ and $\mathrm{T}_{3}$. The higher market price of the mud crab (suitable for stocking in grow-out ponds) produced in ponds with 0.30 million juvenile.ha ${ }^{-1}$, substantially increased the net benefit compared to smaller fingerlings that produced in other treatments with higher stocking densities [37]. Overall, highest growth, survival and benefits of juvenile culture were recorded at a density of 0.025 million juvenile.ha-1.

The mangrove crab is omnivorous and feeds on raw crushed fish, crustaceans, bivalves, molluscs, penaeids and detrital matter. The application of trash fish as feed, the presence of naturally occurring food and muddy nature favored the growth of juvenile of mud crab [38]. Growth of juvenile to a greater extent depended on the quality of food available. In the present investigation, the amount of trash fish given in different treatments was based on the number of juveniles stocked and amount of feed provided per individual was kept at the same level. Hence, the observed low growth at higher stocking densities could be due to less availability of canabolism 


\section{International Journal of Oceanography \& Aquaculture}

character and some variations in environmental parameters [3]. The results in the present experiment were very similar to those of Escritor, Samonto and Agbayani, Mwaluma, and Bensam [32,4,38,37].

About two species of mud crab Scylla serrata and Scylla olivacea were identified [19]. The percentage of S. serrata was found 44.82, 29.40 and $26.77 \%$ which was comparatively lower than S. olivacea. Total production of S. serrata was recorded 2343.74, 1391.47 and $1038.46 \mathrm{~kg}$ which were also comparatively lower than S. olivacea. This was due to poor wild stock of S. serrata in the coastal area.

Finally, it can be concluded that the survival, growth, production of mud crab genera Scylla juvenile were inversely related to the stocking densities of juveniles. Stocking density of 0.025 million juvenile.ha- ${ }^{-1}$ may be advisable for rearing of mud crab juvenile for 135 days culture period. Production of adequate quality and quantity mud crab through application of present findings might be extremely helpful towards the protection of mud crab from extinction as well as for its conservation and rehabilitation.

\section{Acknowledgements}

The author wish to thank Project Director, Culture of cuchia and crab in the selected area of Bangladesh and Research Project, Department of Fisheries, Bangladesh who helps for successfully conducting the experiments with financial support.

\section{References}

1. Cowan L (1984) Crab farming in Japan, Taiwan and the Philippines. Queensland Department of Primary Industries, Brisbane, Qld. Australia Information Series Q184009, pp: 43-61.

2. Chen TP (1976) Crab culture. Aquaculture practices in Taiwan. London Fishing News, pp: 123-128.

3. Catanaon CC (1972) Crab farming in the Philippines. World farming 14: 9.

4. Samonto GPB, Agbayani RF (1992) Pond Culture of mud crab (Scylla serrata). An economic analysis. SEAFDEC-Asian Aquacult 14(4): 3-5.
5. Trino AT, Rodriguez EM (2002) Pen culture of mud crab Scylla serrata in tidal flats reforested with mangrove trees. Aquaculture 211(1-4): 125-134.

6. Baliao DD, Rodriguez EM, Gerochi DD (1981) Culture of mud crab Scylla serrata (Forskal) at different stocking densities in brackish water ponds. SEAFDEC Aquaculture Department Quarterly Research Report 5(1): 10-14.

7. Chang WW (1997) Pen culture of mud crabs in the mangrove ecosystems in Sarawak (East Malaysia). Aqua Asia II no, pp: 3-5.

8. Alferez VN (1977) Engineering aspects and problems in the design and construction of fish pens and fish cages in Laguna Lake, Philippines. In: Joint SCSP/SEAFDEC Workshop on aquaculture engineering 2(15): 373-388.

9. Beveridge MCM (1984) Cage and pen fish farming. Carrying capacity models and environmental impact. FAO Fish Tech Pap 255: 131.

10. Baguilat $T$ (1979) The fish pen industry (of the Philippines): An Overview. SEAFDEC 134-138.

11. Rabanal HR (1988b) History of aquaculture. ASEAN/UNDP/FAO Regional Small Scale Coastal Fisheries Development Project. Manila Philippines ASEAN/SF/88/Tech Pap 1: 13.

12. Chakraborty BK, Azad SA, Samir S (2018) Present Status of Mud Crab Population in Bangladesh. International Journal of Oceanography and Aquaculture 2(2): 000134.

13. Brown IW (1993) Nearshore marine resources of the South Pacific: Information for fisheries management and development. Wright A, Hill L (Ed.), Forum Fisheries, pp: 611-642.

14. Naylor R, Drew M (1998) Valuing mangrove resources in Kosrae, Micronesia. Environ Dev Econ 3(4): 471-490.

15. Marichamy R, Rajapackiam S (2001) The aquaculture of Scylla species in India. Asian Fish Sci 14: 231-238.

16. Brown ME (1957) Experimental studies on growth. In: The physiology of fishes. Brown ME (Ed.), Academic Press, New York 1: 361-400. 


\section{International Journal of Oceanography \& Aquaculture}

17. Castell JD, Tiews K (1979) Report of the EIFAC, IUNS and ICES Working Group on the Standardization of Methodology in Fish Nutrition Research. (Hamburg, Federal Republic of Germany, 21-23 March, 1979). Fisheries and Environmental Sciences 36: 24.

18. Gangadhara B, Nandeesha MC, Varghese TJ, Keshavanath P (1997) Effect of varying protein and on the growth of Rohu, Labeo rohita. Asian Fish Sci 2: 139-147.

19. Keenan CP, Davie PJF, Mann DL (1998) A revision of the genus Scylla de Hann, 1433 (Crustacea: Decepoda: Brachyura: Portunidae). Raffles Bulletin of Zoology 46(1): 217-245.

20. Shang YC (1990) Aquaculture economics analysis: an introduction. In: Advances in world aquaculture 2 (Eds.) Sandifar PA. World Aquaculture Society.

21. Duncan DB (1955) Multiple range and multiple Ftestes. Biometrics 11: 1-42.

22. Zar JH (1984) Biostatistics. Prentice-Hall, Inc. Englewood Cliffs, New Jersey, USA, pp: 718.

23. SAS Institute (1988) SAS/STATTM Users Guide. Release 6.03 (Edn.) SAS Institute Cary, NC.

24. Brett JR (1979) Environmental factors and growth. In: Hoar WS, Randal DJ, Brett JR (Eds.), Environmental relations and behavior Fish Physiology 6: 599-677.

25. Bhuiyan AL, Islam MJ (1981) Tolerance and distribution of Scylla serrata in response to salinity of Karnafully river estuary. Bangl J Agric 6: 7-15.

26. APHA (1998) Standard methods for the examina-tion of water and wastewater. 20 th (Edn.), American Public Health Association Washington DC, pp: 1-733.

27. Clesceri LS, Greenberg AE, Trussell RR (1989) Standard Methods of the Examination of Water and Wastewater 17th (Edn.), American Public Health Association, American Water Works Association and Water Pollution Control Federation 1015 Washington DC, pp: 10-203.
28. Boyd CE (1982) Water Quality Management for Pond Fish Culture. pp: 318.

29. Chen LC (1990) Mud crab culture. In: Aquaculture in Taiwan. Fishing News Books, pp: 142-149.

30. Baliao DD, De Los Santos MA, Franco NM (1999) Pen culture of mudcrab in mangroves. Tigbauan Iloilo Philippines: SEAFDEC Aquaculture Department 26: 10.

31. Cholik F, Hanafi A (1992) A review of the status of the mud crab (Scylla spp.) fishery and culture in Indonesia. In: The Mud Crab, Angell CA(Ed.), pp: 1328.

32. Escritor GL (1972) Observations on the culture of the mud crab Scylla serrata. Coastal Aquaculture in the Indo Pacif Reg Fishing News, pp: 355-361.

33. Trino AT, Millamena OM, Keenan C (1999) Commercial evaluation of monosex pond culture of the mud crab Scylla species at three stocking densities in the Philippines. Aquaculture 174(1-2): 109-118.

34. Fielder DS, Mann DL, Heasman MP (1988) Development of intensive pond farming techniques for the mud crab Scylla serrata (Forskal) in Northern Australia. FIRTA Project Report 86/9, pp: 37.

35. Johnson WE (1965) On mechanism of self regulation of population abundance in Oncorhynchus nerka. Mitt Int Verein Theor Angew 13(1): 66-87.

36. Houde ED (1975) Effect of stocking density and food density on survival, growth and yield of laboratory reared of sea Brea, Archosargus rhomboidales (L.) (Sparidae). J Fish Biol 7(1): 115-127.

37. Bensam P (1986) Culture experiment on the crab Scylla serrata (Forskal) at Turiconin during 19751977 to assess growth and production. Proc Symp Coast Aqua 4: 1183-1189.

38. Mwaluma J (2001) Pen Culture of the Mud Crab Scylla serrata, in Mtwapa Mangrove System, Kenya. Western Indian Ocean J Mar Sci 1(2): 127-133. 